\title{
ADAPA RECONSIDERED: LIFE AND DEATH IN CONTEXTUAL PERSPECTIVE
}

\author{
William W Hallo \\ Yale University ${ }^{1}$
}

In all ages of civilization, men have challenged the brutal reality of death with two unconquerable dreams: one the hope of longevity, long life, and the other the illusion of immortality, of eternal life. Let us see first what the Bible has to say on the second of these two subjects, and then try to retrace our steps to the older lands of the Fertile Crescent and their traditions. However, far be it from me to survey all the twenty-four books of the Bible or all the vast literature of the cuneiform and hieroglyphic sources. I will confine myself instead to a type of expression common to the whole ancient world, namely epic literature.

Epics in the narrow sense are heroic tales of the mighty men of the past, set to poetry or, at least, written with a high degree of literary polish. They differ from myths only in that the latter are poems about gods, not men; they are quite different form legends, which are not poems at all but unsophisticated prose narratives of the popular imagination, or folklore. On this basis, the great classical masterpieces of Homer, Hesiod and Virgil are epics. So are those two most famous works of cuneiform literature, the "Epic (better: myth) of Creation" and the Epic of Gilgamesh. But the Israelites, too, had their epics. About the time that the Iliad and Odyssey were being written in Greece, a royal scribe of the United Monarchy was composing a Hebrew epic recounting the glorious exploits of Saul, Jonathan and David which later became a part of the books of Samuel. And some Biblical scholars find an epic substratum in the Book of Numbers or even regard all the historiographic portions of the Hebrew Bible leading up to this period as an epic created at the same approximate time, though others dispute this. ${ }^{2}$

But epics, like myths, frequently have a second purpose besides or behind the mere telling of a beguiling story - although that in itself is a perfectly meritorious aim. Very often they serve to "explain" some current phenomenon, or some eternal mystery. Where the scientist of today might prefer to furnish a causal analysis, they offer a "historical" analysis or "aetiology," i.e., the explanation of a presently observed condition by appeal to an imaginary one-time event in the past. In other words they use the "punctual" to explain the "durative."

Here is an example from Mesopotamian mythology. Its point is simple: to explain the origin of that trifling but annoying natural phenomenon, the toothache. It begins grandiloquently, but moves quickly from the sublime to the ridiculous.

1. The substance of this paper was delivered as a lecture in Cincinnati more than forty years ago, and alluded to in passing since then; cf. e.g. JCS 23 (1970) 60, n. 36. Its central conclusions remain valid and, as far as I am aware, original. They are here presented in tribute to Yehoshua Gitay.

2. See most recently Shemaryahu Talmon, "Did there exist a Hebrew National Epic?" Pp. 91-111 in idem, Literary Studies in the Hebrew Bible (Jerusalem/Leiden: Magnes/Brill, 1993); reprinted from pp. 41-61 in Proceedings of the Seventh World Congress of Jewish Studies: Studies in the Bible and the Ancient Near East (Jerusalem: Magnes, 1981).

3. Hallo, William W, "Lugalbanda Excavated," JAOS 103 (1984) 165-180, esp. p. 170; reprinted in Studies in Literature from the Ancient Near East ... dedicated to Samuel Noah Kramer, ed. Sasson, JM (New Haven: American oriental Society, 1984). 
After Anu (the supreme god) had created heaven,

and heaven had created the earth,

and the earth had created the rivers,

and the rivers had created the canals,

and the canals had created the marsh,

and the marsh had created the worm:

then the worm went, weeping, before Shamash (the sun god),

his tears flowing before $\mathrm{Ea}$ (the water god),

(saying:) what will you give me for my food?

What will you give me for my sucking?

(The god answered:) I will give you the ripe fig and the apricot.

(The worm:) Of what use are they to me, the ripe fig and the apricot?

Lift me up and among the teeth and the gums cause me to dwell.

The blood of the tooth I will suck,

and of the gum I will gnaw its roots.

(There follows a prescription for dealing with the resulting toothache.) So by this little aetiological myth, the cause and origin of all toothaches is traced back to a kind of oversight in the creation of the world - the "worm" too had to have his niche in the scheme of things even if that niche was, unfortunately, hollowed out of men's teeth. ${ }^{4}$

This kind of epic material, on a much grander scale, also forms a part of the Hebrew Bible. Some of the oldest material within it, sometimes identified as the J-source or "The Book of J," can be described as an epic that begins with the origins of things. ${ }^{5}$ It is not obsessed with the origins of all things, for it does not aim at a systematic approach. But among the eternal questions that it takes up at the very outset are those of immortality and longevity. The first place in an epic is an important one; the subject of the whole epic is very likely announced there, as it clearly is in many Mesopotamian and classical epics. ${ }^{6}$ Note, therefore, the great prominence given to the question of life and death in this, the second Biblical version of creation. I quote Genesis 2:4b-17, omitting the mysterious geographical insert constituted by verses 10-14, from the New Jewish Version (NJV):

When the Lord God made heaven and earth - no shrub of the field being yet in the earth and no grains having yet sprouted, because the Lord God had not sent rain upon the earth and there was no man to till the soil, but a flow would well up from the ground and water the whole surface of the earth - the Lord God formed man from the dust of the earth, and He blew into his nostrils the breath of life; and man became a living being. The Lord God planted a garden in Eden, in the east, and placed there the man whom He had formed. And from the ground the Lord God caused to grow every tree that was pleasing to the sight and good for food, with the tree of life in the middle of the garden, and the tree of the knowledge of good and bad... The Lord God took

4. Translation adapted from Speiser, EA pp. 100f. in Ancient Near Eastern Texts Related to the Old Testament, ed. Pritchard. JB (2nd ed., Princeton: Princeton U.P., 1955). For other incantations against the worm (tultu) see YOS 11 (1985) Nos. 3-5.

5. For a highly controversial translation and interpretation, see David Rosenberg and Harold Bloom, The Book of J (New York: Grove Weidenfeld, 1990).

6. See in detail pp. 177-179 in Hallo, Origins: the Ancient Near Eastern Background of Some Modern Western Institutions (Leiden etc.: Brill, 1996); Streck, M “Die Prologe der sumerischen Epen," Orientalia 71 (2002) 189266. 
the man and placed him in the Garden of Eden, to till it and tend it. And the Lord God commanded the man, saying, "Of every tree of the garden you are free to eat; but as for the tree of the knowledge of good and bad, you must not eat of it; for as soon as you eat of it, you shall be doomed to die.

Let us consider this passage all by itself, without the overtones invariably associated with it when it is read in the light of that other creation which begins "In the beginning God created ..." (NJV: "When God began to create ...), and also without the benefit of later Rabbinic interpretations. Then we must admit that what the passage tells us about is the origin of life human life first, and then, in the continuation, animal life, which is justified by the statement "It is not good for man to be alone" (Gen. 2:18-20). Why was man created? Why did God cause human life to be on the earth? Because, we were told, when there was no man to till the soil then there could be no shrub of the field on the earth and no grain had yet sprouted. But as soon as God had created man, He also caused plants and trees to grow in the Garden of Eden, and placed the man there to till it and tend it.

How does this objective exposition of this Biblical version of the creation of life compare with the treatment of the same theme in ancient Near Eastern epic literature? The Babylonian "Epic of Creation" goes through five of its seven chapters (tablets) before answering that question. When chapter six opens, we find Marduk addressing Ea, the wise old water god of "the Worm and the Toothache," in the assembly of the gods.

When Marduk heard the speech of the gods,

He was resolving to do artful things:

He would tell his ideas to Ea,

What he thought of in his heart he proposes.

"I shall compact blood, I shall cause bones to be,

I shall make stand a human being, let 'Man' be its name.

I shall create humankind.

They shall bear the gods' burden that those may rest."7

In other words, the Babylonian epic poet conceived of the origin of human life as answering the needs of the gods: they wanted a lesser creature to do the menial tasks which otherwise, it seems, they would have had to perform themselves. This is stated in a similar way a few lines later (33-36):

From his (Kingu's) blood he made mankind,

He imposed the burden of the gods and exempted the gods.

After Ea the wise had made mankind,

They imposed the burdens of the gods on them!

An older Babylonian myth, the so-called Atra-hasis Epic, is even more explicit about the motivation for the creation of human life. It too is set in the primeval assembly of the gods. This time the job of creating humankind is assigned to the mother goddess, variously known as Belet-ili ("mistress of the gods"), Nin-tu(d) ("lady who gives birth"), or simply Mami. Ea is speaking (lines 189-197):

7. Benjamin R Foster, p. 400 in The Context of Scripture vol. 1: Canonical Compositions from the Biblical World, ed. Hallo, WW and Younger, KL jr. (Leiden etc.: Brill, 1997). Hereafter abbreviated COS 1. 
"Belet-ili, the midwife, is present,

Let the midwife create a human being,

Let man assume the drudgery of god."

They summoned and asked the goddess,

The midwife of the gods, wise Mami:

"Will you be the birth goddess, creatress of mankind?

Create a human being that he bear the yoke,

Let him bear the yoke, the task of Enlil,

Let man assume the drudgery of god." $" 8$

After the goddess has heeded the request, she says (lines 237-241):

"You ordered me the task and I have completed (it)!

You have slaughtered the god (Aw-ilu) along with his inspiration.

I have done away with your heavy forced labor,

I have imposed your drudgery on man.",

Most explicit of all is still another Mesopotamian myth, later than either of those already dealt with, but including a version in Sumerian followed, in a parallel column, by a translation into Akkadian, ${ }^{10}$ a relatively unusual format in the long tradition of Mesopotamian bilingual literary texts. ${ }^{11}$ The gods are once more in their assembly. They discuss what to do now that the physical world has been created, and answer themselves as follows, in Heidel's translation (lines 24-40):

In Uzumua, the bond of heaven and earth,

Let us slay (two) Lamga gods.

With their blood let us create mankind.

The service of the gods be their portion,

For all times

To maintain the boundary ditch,

To place the hoe and the basket

Into their hands

For the dwelling of the great gods,

Which is fit to be an exalted sanctuary,

To mark off field from field.

For all times

To maintain the boundary ditch,

To give the trench (its) right course,

To maintain the boundary stone,

To water the four regions of the earth,

To raise plants in abundance, etc. etc. ${ }^{12}$

8. $\operatorname{COS} 1: 451$.

9. Ibid.

10. The first column contains the elementary syllabary me-me pa4-pa4. For the possible significance of this juxtaposition, see Gadd, CJ, “The Infancy of Man in a Sumerian Legend," Iraq 4 (1937) 33f.

11. For other examples see Hallo, Origins (1996) 159 and n. 82.

12. KAR 4 as translated by Alexander Heidel, The Babylonian Genesis: the Story of Creation (2nd ed., 
All these epic traditions have a common element: the purpose of human life is the tilling of the soil and the raising of plant life. In Babylonian mythology, this purpose in turn has an ulterior motive, namely to provide the gods - who are pictured as sharing all the human appetites - with their food requirements by way of sacrifices; in the Bible, on the contrary, the command to till the soil is followed by the permission to man to enjoy by himself the fruits of his labors (Gen. 2:15f.). Nor does the Biblical account call for the slaying of a god or gods to provide the stuff of man. So in both of these respects it is more dignified and less offensive than the Babylonian account. But these differences should not obscure the wider implications of both traditions: the interdependence of human, animal and plantlife on this unique planet.

So much for the origin of life. But the Biblical epic of creation also had something to say about the origin of death. For when God commanded Adam to enjoy the fruits of his labor he made an exception (Gen 2:16f.):

And the Lord God commanded the man saying, "Of every tree of the garden you are free to eat; but as for the tree of the knowledge of good and bad, you must not eat of it; for as soon as you eat of it, you shall be doomed to die.

The phrases translated "you are free to eat" and "you shall be doomed to die" are both "paranomastic infinitives" in the original Hebrew, i.e. they use one and the same verbal root in immediate juxtaposition, once in infinitive absolute form and once in finite form. The paranomastic infinitive is a subtype of a construction variously known as inner accusative, figura etymologica, or cognate accusative. It occurs throughout the Semitic languages, including Akkadian, ${ }^{13}$ Ugaritic, ${ }^{14}$ and Arabic. ${ }^{15}$ But it is particularly common in Biblical Hebrew, where its function is "to define more accurately" or "to strengthen the idea of the verb," according to the standard grammars. ${ }^{16}$ The effect is one, however, not only of emphasis but also of a greater solemnity, of a slowing down of the action, of subjecting it to a more deliberate pace. ${ }^{17}$ A literal translation would therefore be, in the first instance, "you shall eat an eating" and, in the second, you shall die a dying," but an idiomatic translation, truer to the letter and spirit of the original Hebrew, would be, "you shall make a meal" and "you shall meet with death/be subject to death," respectively. They are clearly solemn commands, in the first case explicitly so (2:16). There is no basis in Hebrew syntax for the "permissive" meaning attributed to the former phrase, or even for the judgmental implication attributed to the latter.

Note that death is not introduced as something inevitable. We were told that "the Lord God formed man from the dust of the earth, and He blew into his nostrils the breath of life; and man became a living being," (2:7) but not that God created death. Death is apparently only a contingent possibility: if man eats of the tree of the knowledge of good and bad, then only shall he meet death. As for the rest of the trees in the Garden of Eden, all these man was free, indeed commanded, to eat.

Chicago/London: University of Chicago Press, 1951), 69f. For a more recent translation into German, see Giovanni Pettinato, Das altorientalische Menschenbild, $74 \mathrm{ff}$.

13. Julius Lewy, "Paranomastic Infinitives in Classical Akkadian," Orientalia 15 (1946) 410-415. For an example from Adapa, cf. B 51: tamta ina meseli imsilma, translated "he cut the sea in half" by Izre'el Adapa (2001) 97, "both halves of the sea were completely the same" by Dietrich, AOAT 42:47.

14. Gordon, Cyrus, H, Ugaritic Handbook (= Analecta Orientalis 25) (Rome: Pontifical Biblical Institute, 1947) 68 par. 9.23 and n. 1.

15. Thatcher, GW, Arabic Grammar of the Written Language (4th ed., London: Lund Humphries, 1942) $237 \mathrm{f}$.

16. Kautsch, E, ed., Gesenius' Hebrew Grammar, tr. Cowley, AE (2nd ed., Oxford: Clarendon, 1910) 342f., par. 113.1-s.

17. Hallo, “A Problem of Translation," paper delivered to SBL, NY, December 30, 1958. 
Now what were the other trees in the Garden? The earlier verse (2:9) spoke specifically of "every tree that was pleasant to the sight and good for food, with the tree of life in the middle of the garden, and the tree of the knowledge of good and bad." In other words, God's explicit command to eat of every tree but one in the garden implicitly included the tree of life. If this is not what the passage means to say, then the narrator is guilty of a careless error at perhaps the most crucial point of the whole narrative!

And what would be the consequence of eating from the tree of life? As the name implies, its fruit is life, and not just life but eternal life. The continuation of the narrative says as much. God, apparently taking counsel with his own divine assembly - note the plural in "like one of us" - says (3:22-24):

Now that the man has become like one of us, knowing good and bad, what if he should stretch out his hand and take also from the tree of life and eat, and live forever!

So the Lord God banished him from the Garden of Eden, to till the soil from which he was taken. He drove the man out, and stationed east of the Garden of Eden the cherubim and the fiery ever-turning sword, to guard the way to the tree of life.

So what has happened in this all too familiar tale? Man ate the fruit of death, though he was commanded not to do so, but he did not eat the fruit of life, though he was in fact commanded to do just that. God commanded life, but man chose death. For this mistake or, as Milton, called it, "man's first disobedience," he was forever prevented from again availing himself of the divine command to taste eternal life.

Have I been reading between the lines? Eliciting ideas that are not in the text? Imputing modern notions to the ancient story-teller? I don't think so. For the epic literature of the ancient Near East once more comes to our aid. The problem of the loss of immortality or, what amounts to the same thing, the beginnings of mortality, is one of its main concerns. Let me illustrate this with the Epic of Adapa.

According to Mesopotamian traditions, Adapa was one of the seven wise men (apkallu) at the beginning of time, perhaps the first of all men, for in a lexical text his name is equated with a word meaning simply "human being" $($ amilu $) .{ }^{18}$ In Sumerian, his name can be explained as "recovered (pa3) from the water $(a-d a),{ }^{19}$ and he is later equated with $u 4$-an, the Greek Oannes, as the first of the semi-divine creatures who brought the arts of civilization to Sumer, ${ }^{20}$ or with Utu-abzu, "born of the sea." ${ }^{, 21}$ In Akkadian, he is the protagonist of his own epic. Ea, the wise old water-god, had created him as a model(? $)^{22}$ of men, making him wise, blameless, ritually clean, and skilled in the service of the gods (for which he had presumably been created). "But eternal life he did not grant him."23

Adapa's special relationship was with Ea; one version of the text even calls Adapa "son of Ea" (B 12), but another may have had instead "son of Eridu"24 and this is his epithet elsewhere

18. $a-d a-a b=a-m i-l u$ in the lexical series $1 \mathrm{u}=4 a$ I 20; MSL 12 (1969) 93; the equation was first noted by Ebeling,

E. Tod und Leben nach den Vorstellungen der Babylonier (Berlin/Leipzig: 1931) 27a; cf. Speiser in ANET 101, n.

19. Cf. tul-ta-pa3-da ("recovered from the well") as a foundling name.

20. Hallo, Origins (1996) 7 and nn. 50f.

21. Parpola, Simo, Letters from Assyrian and Babylonian Scholars (= SAA 10) xxxv n. 29.

22. If read ki-ma red-di ina a-me-lu-ti, with Speiser, Anet. Von Soden considers 'as successor (to Ea) among men' ("als Nachfolge unter den Menschen”): Kramer AV (1976) 428. But Piccioni reads sed-di and translates as if sedi, "protective spirit." Foster, Benjamin R Before the Muses (Bethesda, MD: CDL, 1993) 434: "Translation uncertain."

23. Foster, Before the Muses 430, line 4.

24. Cf. Stephanie Dalley, Myths from Mesopotamia (Oxford/New York: Oxford University Press) 188 n. 7. Note that 
in the story. The link with Eridu, the first city in Mesopotamian tradition, takes on new significance in light of the discovery of a Sumerian version of the Adapa story among the literary tablets from Me-Turan. ${ }^{25}$ It is also not without significance from a comparative perspective, for according to my reading of Gen. 4:17, "Cain knew his wife and she conceived and bore Enoch, and he (Enoch) became the (first) builder of a city, and he called the name of the city according to the name of his son (i.e., Irad), did Eanoch." ${ }^{26}$

Adapa's special skill (already at the beginning of civilization we are confronted with specialization) was sailing a boat and catching fish for the temple of Ea. One day, as he was steering his boat, the South Wind ${ }^{27}$ kicked up such a storm that Adapa, as he later said in his own defense, "spent the rest of the day in the home of the fish., ${ }^{28}$ (For the "home of the fish" in Sumerian tradition see Civil and, differently, Thomsen. ${ }^{29}$ ) But Adapa was equal to the challenge. He simply broke the wings of the South Wind. Thereupon he was summoned before the tribunal of the great gods, including the greatest of the gods, Anu, the personification of Heaven.

Ordinarily, this was no small matter. But Adapa had the help of Ea who, though not the greatest, was always the wisest of the gods. Ea gave him his advice. He told him exactly what to expect when he got to heaven, and how to behave. Among other things he carefully instructed him:

When you come before Anu,

They will proffer you food of death, do not eat!

They will proffer you waters of death, do not eat ${ }^{30}$

Armed with this advice, Adapa was brought to the gate of heaven, guarded by Dumuzi and Gizzida, and thence before the great gods and the Investigation was begun by Anu:

"Come now, Adapa, why did you fracture the wing of the south wind?"

Adapa answered Anu,

"My lord, I was fishing in the depths of the sea,

For my master's temple.

The sea was like a mirror.

Then the south wind blew upon me and capsized me.

I spent the rest of the day in the home of the fish. ${ }^{31}$

In my fury, I cursed the wind., ${ }^{32}$

Adapa is specifically the "seed of humankind" (zer ameluti) in Fragment D 12; see Picchioni, SA Il Poemetto di Adapa (Budapest:ELTE, 1981) $122 \mathrm{f}$.

25. Cavigneaux, Antoine and al-Rawi, Farouk, "New Sumerian Literary Texts from Tell Haddad (ancient Meturan): A First Survey," Iraq 55 (1993) 91-105, esp. p. 92. They note that ISET 1:156 Ni. 4436, a fragmentary text from Nippur, proves to be a duplicate.

26. Hallo, "Urban Origins in Cuneiform and Biblical Sources," in Mites de fundacio de ciutats al mon antic (Mesopotamia, Grecia i Roma), ed. Azara, Pedro et al. (Barcelona: Centre de Cultura Contemporania, 2001) $37-$ 50, with previous literature.

27. Akkadian sutu; though not preceded by the semantic indicator (determinative) for divinity, the context implies the personification or even deification of the wind.

28. So Foster, Before the Muses 433:66 based, presumably, on a reading a-na bi-i-t [u nu-ni]-i u-sa-am-si-i-[il-su], i.e. from sumsulu). Cf. Picchioni, Adapa 118:66. For a totally different understanding by Izre'el see below, n. 62.

29. Civil, M, “The Home of the Fish,” Iraq 23 (1960) 154-175; Thomsen, Marie-Louise “"The Home of the Fish': a new Interpretation,” CS 27 (1975) 197-200.

30. Foster, Before the Muses 432:35-37.

31. Kienast, B, Festschrift Lubor Matous (Budapest: ELTE, 1978) vol. 1:182f. reads here bi-it be-li-(ja), but this reading is unlikely in Amarna Akkadian. 
Herewith, the "defense rests," and the gods take counsel. They know that Ea has forewarned Adapa and they must find a way to outsmart him. Listen to them now:

"Why did Ea disclose the meaning (lit. heart) ${ }^{33}$ of heaven and earth to a mere mortal (lit.: worthless humanity)? He has made him distinguished (lit.: fat).

He has made him immortal (lit:: made a name for him)! As for us, what shall we do about him?? ${ }^{34}$

So they decide to bring him food of life ${ }^{35}$ and water(s) of life rather than (as Ea had predicted) of death. (Again, food of life and water of life already occur, and occur together, always in this order, in Sumerian literature, in myth $^{36}$ and epic ${ }^{37}$ as well as in "letter-prayers." ${ }^{38}$ ) Of course, Adapa refused it, and therewith he refused eternal life. As the heavenly session concludes:

Anu stared and burst out laughing at him.

"Come now, Adapa, why did you not eat or drink?

Won't you live? Are not people to be immortal?"

(Adapa:) "Ea my lord told me, 'You must not eat, you must not drink.'

(Anu:) "Let them take him and return him to his earth.,"39

On its surface, this story has some considerable differences from the Biblical tale. Adapa's name is interpreted as meaning "recovered from the water" while Adam is named for the earth from which he was made. The entrance to Heaven is guarded by two deities, Dumuzi and Gizzida, while the entrance to Eden is barred by an indeterminate number of cherubs armed with a flaming, whirling sword (Gen. 3:24).

In spirit and in its deeper meaning, however, this story presents us with one of the profoundest parallels between cuneiform and Biblical literature. Both express the notion that God offers life but man chooses death. Indeed, the earliest and principal exemplar of the Akkadian story was found not in Mesopotamia but in Egypt of the Amarna period, and dates from the 14th century, so the possibility of a generic connection with the Israelite version cannot be ruled out. How has recent scholarship on Adapa viewed this possibility?

The close parallelism between the two tales was recognized early and often after the first publication of the main exemplar from Amarna by Winckler and Abel more than a century ago. ${ }^{40}$ That it has not been universally acknowledged in more recent scholarship is mainly due to the fact that the tree of death is not so named in the Biblical narrative. Instead it is called the

32. Foster, Before the Musus, 432f.: 60-67.

33. This is demonstrably a meaning of the Sumerian word for "heart."

34. Lines 71-75, my translation. In distinction to previous translators, I take the accusative libba in line 73 to be the second object of the doubly transitive ukillimsi of the preceding line, and sa same_u erseti as a kind of "anticipatory genitive" to libba. The peculiar spelling su-u-ma is paralleled by numerous other 'unorthographic plene-spellings' in the Amarna exemplar to which attention was called by Kienast, Festschrift Matous 183 and 197, n. 8. Among diverging translations, see esp. Bing, UF 16 1984) 54.

35. Akal balati; some translate here "bread of life" but "food of life" is closer to Sumerian ú-nam-ti-la for which see next note.

36. Samuel Noah Kramer, “'Inanna's Descent to the Nether World' continued and revised," JCS 5 (1951) 1-17, lines $66,221 f$.

37. Hallo, "Lugalbanda Excavated," JAOS 103 (1983), rep. Studies Kramer 2 (1984) 172-175:260-263;

38. Hallo, "The Royal Correspondence of Larsa: I. A Sumerian prototype for the Prayer of Hezekiah?", Studies Kramer (= AOAT 25, 1976) 220f.:50 and 224 ad loc.; idem, "Two Letter-Prayers to Amurru," Studies Gordon 4 (1998) 406:6f.

39. Foster, Before the Muses 433:81-85.

40. Winckler, Hugo and Abel, Ludwig, Der Thontafelfund von El Amarna II/2 (Berlin: Spemann, 1890), No. 240. 
tree of the knowledge of good and evil, which is interpreted by some to represent moral discernment and the ability to make ethical choices, and by others as a "merism," a syntactical construction implying totality. ${ }^{41}$ On either interpretation, however, it is functionally equivalent to a tree of death, for eating of it means death - and not just death but mortality, while eating of the tree means not just life but immortality. ${ }^{42}$

New interpretations of Adapa have appeared almost annually. We will confine our survey to the last thirty years, beginning in $1973 .{ }^{43}$ Two contributions appeared in that year. The first, by Buccellati, found that Adapa had more in common with Noah and Abraham than with Adam. ${ }^{44}$ The second, by Kienast, conceded that food and water of life would have conveyed eternal life, but proposed that Adapa was meant to refuse them because mortality had already been ordained for humanity. ${ }^{45}$ Two years later, Foster criticized the view that if Adapa "had eaten of the bread and drunk of the water men would all be immortal." He allowed that the Adapa story had some stylistic and substantive similarities to this part of the $\mathbf{J}$ document, but he could "see no possibility for a further rapprochement of Adapa and Adam." ${ }^{, 6}$ Two years later, von Soden provided important collations, new readings, and possibly new texts for the epic, but declined to deal with its comparative aspects. ${ }^{47}$ At the same time, Xella dealt with Adapa in the context of ancient Near eastern mythology generally. ${ }^{48}$ Kienast returned to the subject in 1978 , but also without raising the comparative issue. The same is true of Michalowski's contribution of $1980 .^{49}$

Picchioni's edition of 1981 marked a new stage in the study of the poem. ${ }^{50}$ Besides presenting anew every known or suspected exemplar of the composition, he edited the relevant passages from all other literary texts mentioning Adapa. Although avoiding comparative issues, he encouraged renewed interest in the text and its implications. The following year, Liverani dealt with "Adapa e Adamo" in an appendix to his essay on the text. While noting that the two myths are indubitably similar ("due miti indubbiamente cosi simili"), he emphasized the differences between them, taking Adam as a prototype of humanity in general and Adapa as a primordial priest. ${ }^{51}$ He was followed the next year by Müller, who emphasized the mythological character of the story. ${ }^{52}$ One year later, Bing reaffirmed the Adapa myth's

41. For both possibilities cf. Sarna, Nahum M, Genesis (= The JPS Torah Commentary 1) (1989) 19, who prefers the latter interpretation. For another example of Biblical merism ("right and left") see Cohen, Chayim Encyclopaedia Judaica 14 (1972) 179.

42. This is essentially also the view of Gaster, Theodor H, Myth, Legend, and Custom in the Old_Testament (New York/Evanston: Harper and Row, 1969), but while he adduces Adapa as a general parallel to "the food of Paradise" (p. p. 29f.), he does not relate him specifically to "the trees of Paradise" (pp. 32-35).

43. For earlier interpretations see all the subsequent treatments.

44. Giorgio Buccellati, "Adapa, Genesis, and the Notion of Faith,” UF 5 (1973) 61-70. E.A. Speiser had compared Adapa to Daniel, according to Foster, Or. 43 (1974) 353, n. 33.

45. Kienast, Burkhart, "Die Weisheit des Adapa von Eridu," Studies Boehl (1973) 234-239. His interpretation owes much to T Jacobsen's earlier treatment in AJSL 46 (1930) 201-203 (rep. TIT 1970:48-51).

46. Foster, Benjamin R, "Wisdom and the Gods in Ancient Mesopotamia," Orientalia 43 (1974) 344-354. He cites my description of the "mythopoeic mode of thought" of 1970 (above, n. 1).

47. Von Soden, Wolfram, "Bemerkungen zum Adapa-Mythos," Studies Kramer (1976) 427-433.

48. Xella, P, Problemi del Mito nel Vicino Oriente Antico (Naples: 1976) 47-60.

49. Michalowski, Piotr, "Adapa and the Ritual Process," Rocznik Orientalistyczny 41 (= Studies Ranoszek) 77-82.

50. Note that Kienast, Studies Matous 1 (1978) 181, considers the main (Amarna) exemplar to be prose.

51. Liverani, Mario, “Adapa ospite degli dei," in Religioni e Civilta (= Studies Brelich) (Bari: Dedalo, 1982) 293-319, esp. pp. 317-319.

52. Müller, Hans-Peter, "Mythos als Gattung archaischen Erzählens und die Geschichte von Adapa,” AfO 29/30 
theme of mortality/immortality that had been questioned by Buccellati and some other interpreters. $^{53}$ In 1988, Sauren dealt with the laughter of An, a recurrent them in the Mesopotamian story, and certainly one of its most striking divergences from the Biblical tale, where divine laughter would be unthinkable. ${ }^{54}$ In 1990, Talon edited the myth and compared it with other Babylonian traditions, but without references to the Biblical tale 55 (1990) 43-57. In the same year, Glassner briefly considered Adapa in the context of the wider question of hospitality in ancient Mesopotamia, concentrating in this connection on the role of Dumuzi and Gizzida. ${ }^{56}$ But he ignored the particular role of Dumuzi suggested by a neo-Sumerian archival text from Birmingham which can be interpreted to show that, upon his death, King Shulgi of Ur ascended to heaven to serve for seven days as doorkeeper of heaven presumably in the guise of Dumuzi! ${ }^{57}$ In 1991 and again in 1993, Dietrich restudied the Amarna exemplar and concluded that "it is basically prose with the presence of only loosely strewn passages in poetry. ...it is a text mixing poetry and verse." ${ }^{58}$ In the latter year, finally, Parpola even provided a mystical interpretation of Adapa and his ascent. ${ }^{59}$

The most recent treatment of the text is by Shlomo Izre'el, who has long made a specialty of studying the literary compositions from El Amarna in general ${ }^{60}$ and Adapa in particular. ${ }^{61}$ He provides a transcription of the text as well as a transliteration, and departs from previous readings and translations in many cases. ${ }^{62}$ But he is keenly aware of potential Biblical parallels, as the very subtitle of his book, taken from Proverbs 18:21, attests. He recognizes that "the biblical myth of the Garden of Eden ... resembles the Adapa myth in significant respects," "63 adding, in a footnote, "In their very essence, both tales recapitulate the basic human dichotomy between life and death versus the no-less-basic dichotomy between knowledge and ignorance, between awareness and innocence."

But in fact he seems to give priority to the second of these two dichotomies, emphasizing that Adam and Eve ate from "the tree of the knowledge-of good-and-bad"65 - not, as I would call it,

(1983-84) 75-89.

53. Bing, JD, “Adapa and Immortality,” UF 16 (1984) 53-56.

54. Sauren, Herbert, "Dieu rit: une interpretation du mythe d'Adapa," in Humour, Travail et Science en Orient, ed. Théodoridés, A et al. (Leuven: Peeters, 1988) 15-30.

55. Talon, Phillipe, "Le mythe d'Adapa," Studi Epigraici e Linguistici 7 (1990) 43-57.

56. Glassner, Jean-Jacques, "L’hospitalité en Mésopotamie ancienne," ZA 80 (1991) 60-75, esp. pp. $72 f$.

57. Hallo, Origins (1996) 202 and nn. 80f.

58. Dietrich, Manfred, "Wurde Adapa um das 'Ewige Leben' betrogen?” Mitteilungen für Anthropologie und Religionsgeschichte 6 (1991) 119-132; idem, "Babylonian Literary Texts from Western Libraries," in Verse in Ancient Near Eastern Prose, ed. de Moor, JC and Watson, WGE (= AOAT 42, 1993) 41-67, esp. p.48; cf. p.43.

59. Parpola, Simo, Letters from Assyrian and Babylonian Scholars (= State Archives of Assyria 10) (Helsinki: Helsinki University press, 1993) xix.

60. Adapa and the South Wind: Language has the Power of Life and Death (= Mesopotamian Civilizations 10) (Winona Lake, IN: Eisenbrauns, 2001).

61. "Some Thoughts on the Amarna Recension of Adapa," Studies Leslau (1991) 211-220; idem, "The Initiation of Adapa in Heaven," RAI 43 (1998) 183-187.

62. Note especially that he derives ultamsil in B 53 from salu. "I was plunged into the lord's house," so that Adapa actually drowned, only to be reborn in heaven! Parpola, SAA 10 p. xviii by contrast says that the antediluvian sages, beginning with Adapa, were endowed with a fish-shape so that they, unlike humans, were able to plunge into "the divine Ocean of Wisdom, Apsu" at will.

63. Ibid., $126 \mathrm{f}$.

64. Ibid., n. 39.

65. Ibid., 127. 
from the tree of death - and concluding that "human life was still a matter of everlasting reality. Consequently, eating from the tree of life would not affect them at all." ${ }^{, 66}$ A strange conclusion, given that the text clearly states that eating of the tree of life would confer immortality, an immortality that may have been foreseen in the command to eat from all the trees except the tree of death, but one that had not yet been realized by the time the tree of death was first tasted. Like so many interpreters before him, Izre'el has been diverted by the pericope about the knowledge of good and evil from seeing the fundamental accord between the two tales.

What then is their message? In spite of all their differences - such as the laughter of $\mathrm{An}^{67}-$ both express the notion that God offers life but man chooses death. In the Akkadian plot, this theme recedes behind the magical or therapeutic use to which the myth was eventually - and perhaps also originally - put. ${ }^{68}$ In the Bible, by contrast, it is one of the most important of themes, recurring throughout all its separate parts. At every turn, God offers the choice, and urges humanity to choose life, or to choose the right way that it may live, often enough constructing a proportion such that life:death = good:evil. ${ }^{69}$ For in death there is no remembrance, and from Sheol, the land of the dead, there is no song of praise to God. ${ }^{70}$ In a sense, the whole Bible is a guide (tora) to those who want to walk in the way of life or, as the Book of Proverbs puts it, the Torah $i$ s the new Tree of Life to those who hold fast to it. ${ }^{71}$

Both the similarities and the differences between the two tales thus help in the interpretation and appreciation of each of them, in the best tradition of the contextual approach. ${ }^{72}$

\section{Abbreviations}

Jacobsen, TIT $=$ Thorkild Jacobsen, Toward the Image of Tammuz and Other Essays ..., ed. William L Moran (Harvard Semitic Series 21) (Cambridge: Harvard University Press, 1970).

Studies Boehl = Symbolae Biblicae et Mesopotamicae Francisco Mario Theodoro Bohl Dedicatae, ed. MA Beek et al. (Leiden: Brill, 1973).

Studies Gordon 3 = Boundaries of the Ancient Near Eastern World: A Tribute to Cyrus H. Gordon, ed. M Lubetski et al. (Sheffield: Sheffield Academic Pres, 1998).

Studies Kramer = Kramer Anniversary Volume, ed. BL Eichler et al. (AOAT 25) (NeukirchenVluyn: Neukirchener Verlag, 1976).

Studies Kramer 2 = Studies in Literature from the Ancient Near East ... Dedicated to Samuel Noah Kramer, ed. Jack M Sasson (AOS 65) (New Haven: American Oriental Society, 1984).

Studies Leslau = Semitic Studies in Honor of Wolf Leslau ..., ed. Kaye, Alan S (2 vols.) (Wiesbaden: Harrassowitz, 1991).

Studies Matous = Festschrift Lubor Matous, ed. Hruska, B and Komoróczy, G (2 vols.) (Budapest: ELTE, 1978).

66. Ibid., 128

67. Above, at n. 54; cf. also e.g. the bad advice offered by the wise, beneficent Ea to Adapa but by the "subtile" snake to the woman.

68. Note that already the Sumerian version from Me-Turan ends in "an incantation-like passage"; Antoine Cavigneaux and Farouk al-Rawi, Iraq 55 (1993) 92.

69. E.g. Deut. 30:15-20, Jer. 21:8-10.

70. Ps. 6:5.

71. Prov. 3:18; cf. 11:30.

72. In its original form (above, n. 1), the paper continued with the origins of childbirth, of murder, of the loss of longevity, and the replacement of immortality by zikir sumi, the remembrance of the name. 